\title{
ТЕКСТ ДОКУМЕНТА - ВАЖЛИВА КОМУНІКАТИВНА СКЛАДОВА ПИСЕМНОГО ДІЛОВОГО МОВЛЕННЯ
}

У статті запропоновано аналіз тексту документа як комунікативної одиниці писемного мовлення. Звернено увагу на культуру мови ділових паперів.

Ключові слова: документ, текст, комунікативні якості, культура діловодства, мовленнєва діяльність.

The article offers an analysis of the text of the document as a communicative unit of writing. The author draws attention to the culture of the language of documents.

Keywords: document, text, communicative qualities, culture of paperwork, oral activity.

Мета статті - осмислити й проаналізувати особливості тексту документа як комунікативної одиниці писемного ділового мовлення.

Актуальність обраної теми зумовлена, насамперед, інтересом до культури мови діловихпаперів.

Важливі комунікативні якості писемного ділового мовлення зосереджені в головному елементі документа, тобто одиниці писемного мовлення - тексті. Мовознавці називають його основною засадою будь-якого документа.

На думку Г. Антипова, О. Донських, Ю. Сорокіна, Г. Вознюка, визначальна функція тексту - бути засобом соціальної комунікації в усіх сферах суспільного життя. Від умілого, грамотного, логічно послідовного викладу матеріалу залежить культура писемного ділового мовлення.

Саме текст і фактична реалізація його - це та проблема вироблення культури письма, вирішення якої передбачає знання законів логічної й лексичної сполучуваності слів, уміння користуватися словесними формулами, розрізняти стильові особливості текстів, добирати до них відповідний мовний матеріал.

Текст як основний елемент писемного мовлення має такі комунікативні якості, як стислість, послідовність викладу матеріалу, лаконічність, смислову точність, логічність, об'єктивність, простоту, виразність мови і стилю, влучність думки. Вони находять своє вираження в мовних конструкціях і словесних формулах текстів різного рівня стандартизації (звітах, ділових листах, договорах, наказах), у логічних елементах (вступі, доказах, висновках).

Проте $є$ чинники, ігнорування яких ускладнює досягнення позитивного результату: надто велика кількість комунікативних якостей текстів, які взаємно доповнюють одна одну, їх важко відмежувати, нелегко провести чіткі межі між ними. 3 огляду на це методисти порушують питання про необхідність звести перелік комунікативних якостей мовлення до прийнятного з дидактичного погляду мінімуму, виокремити серед них найпотрібніші, найзручніші для аналізу й оцінки.

На думку багатьох учених (А. Коваль, Н. Бабич, Л. Паламар, 
3.Куньч,Л. Савенкової, Г. Сагач), проблеми відтворення специфіки ділового текст отвору безпосередньо пов'язані з вибором способів, прийомів передання компонента одиниць різних рівнів мови - ділової, термінологічної лексики, словотвірних засобів, синтаксичних структур.

Поняття високої культури діловодства, культури мови ділових паперів реалізуються в культурі ділового мовлення, у вимогах до складання текстів документів з урахуванням комунікативних якостей, які виявляють себе в конкретних текстах залежно від рівня їх стандартизації (високого і низького).

Ділове текстотворення має необмежені можливості для реалізації мовленнєвої культури в різних ситуаціях, для аналізу мовних засобів (лексичних, граматичних, стилістичних), для формування умінь і навичок мовленнєвої діяльності, оскільки:

- тексти документів містять повідомлення про факти, явища суспільного життя, оцінку ділових і моральних якостей фахівців різних галузей; звіти, інформацію про роботу; конкретні, реальні пропозиції;

- тексти документів уможливлюють спостереження вербальних і невербальних засобів мовлення, відповідність їх цілям, умовам ситуації; аналіз структури мовлення 3 урахуванням його комунікативних якостей; виявлення функцій мовлення (денотативної, комунікативної, сигніфікативної, дейктичної, волюнтативної), створюючи на їхній основі лексико-тематичні групи;

- тексти документів дають змогу формувати оцінне ставлення, критичну чи позитивну думку щодо мовного оформлення тексту; додержання основних правил складання його; виконувати лінгвістичний аналіз, орієнтуючись на види документів, структуру тексту, його семантику; свідомо оволодівати змістом тексту залежно від спеціальності, фаху, яких набуває студент у вищому навчальному закладі;

- тексти документів спрямовані на формування практичних умінь і навичок оформлення матеріалу текстів; на компонування його логічних частин; на вироблення умінь професійно грамотно оцінювати комунікативні можливості текстів документів, 3 якими працюватиме майбутній фахівець у певній сфері виробничої діяльності.

У практиці сучасного діловодства вироблено загальні вимоги до створення текстів документів, основні правила, які забезпечують реалізацію комунікативних якостей ділового мовлення, додержання лексичних, граматичних, стилістичних норм.

Однак тесті документів, пов'язані з бухгалтерською, економічною діяльністю, мають свої аспекти дослідження, аналізу, які висвітлюють проблеми неточності у вживанні бухгалтерських, економічних термінів, доводячи проблему уніфікації їх. Уживання таких термінів, як «первісна вартість» (замість «первинна», «початкова» вартість), «оборотні кошти» (замість «обігові кошти») i т. д., свідчать про неунормованість мови документів, що призводить до неточного, ненормативного вживання відповідних термінолексем.

Порушення законів логічної й лексичної сполучуваності, нерозрізнення омонімів, паронімів, вживання неправильних засобів для формулювання думки в межах фрази та й у ширшому контексті, недоречне вживання типових мовних зворотів, фразеологічних сполук, іншомовних слів - усе це має стати об’єктом дослідження мови текстів ділової документації. 
У грецькій культурі усталилося як мінімум три погляди на слово, на основі кожного з яких побудовано свій об'єкт аналіз - мова, текст, логіка. Першою передумовою усвідомлення тексту (зокрема й тексту документа) стають словесні формули, які виконують різні функції:

- денотативну (називають предмети, явища, ознаки);

- дейктичну (вказують на причини, результати, наслідки);

- волюнтативну (спонукають до виконання певних дій);

- сигніфікативну (узагальнюють процеси, роблять висновки).

Вдалий добір таких словесних формул дає змогу реалізувати названі вище функції в кожному конкретному тексті документа, використовуючи його дидактичні можливості.

Текст документа $є$ основою використання дидактичного матеріалу для різних навчальних робіт. Різнопланова робота з текстами документів охоплює:

- уведення в текст стандартних конструкцій;

- переставлення частин тексту;

- продовження тексту за поданим початком;

- висловлення свого ставлення до проблем, порушених у ділових текстах;

- написання переказів тексту (стислого й докладного);

- редагування тексту;

- роботу над визначенням лексичного значення слова, його ролі й місця в тексті.

Пропонується методичний апарат для роботи з текстами документів, що містить фонетико-орфографічні, граматико-орфографічні, граматико-пунктуаційні, лексикограматичні питання й завдання до текстів.

Важливою умовою грамотно оформленого тексту документа є чітко окреслене завдання.

Якщо потрібно перевірити, наскільки студент орієнтується в конкретній ситуації, уміє їі описати, висловити своє ставлення до неї, пропонуємо завдання на доповнення, продовження думки. Наприклад:

- у тексті звіту:

Я проходив (-ла) навчально-виробничу практику в ...

Під час практики вивчав (-ла) ...

Керівництво підприємства створило всі ...

Я ознайомився (-лася) з ...

Такі початки фраз орієнтують студента на додержання основних вимог до складання ділового тексту, а саме: послідовності викладу думки, конкретності, об'єктивності.

Багатими на синтаксичні моделі-конструкції $\epsilon$ тексти службових листів. Завдання на доповнення, продовження тесту допоможуть перевірити знання функціональних ознак листів-запрошень, листів-прохань, листів-нагадувань.

На нашу думку, важливою формою навчальної роботи 3 формування комунікативних умінь і навичок є редагування текстів документів. Воно реалізується в різноманітних видах вправ, для виконання яких можна застосувати низку методичних прийомів: спостереження над авторським текстом, над власною мовою, 
мовою своїх колег, однокурсників; редагування текстів через синонімічні, патронімічні заміни; застосування вставок, скорочень.

Завдання і вправи на правильний вибір синонімів, граматичних форм для складання тексту документа формують уміння студентів розрізняти значення слів, розвивають чуття мови, інтуїцію.

Небажаним у діловому текстотворі є явище тавтології. Щоб уникнути його, даємо завдання знайти в тексті невиправдані повтори, усунути їх, змінивши конструкцію словосполучення або речення.

Треба критично ставитися до вживання у ділових текстах іншомовних слів, окрім тих, що не мають питомого українського відповідника. Як вправу пропонуємо студентам уважно прочитати діловий текст, виписати 3 нього іншомовні слова й замінити їх українськими.

Завдання вищої школи - підготувати висококваліфікованих, грамотних фахівців, які б добре володіли українською мовою. Спеціаліст, який має справу 3 діловими паперами, документами, зобов'язаний опанувати лексичне й фразеологічне багатство ділового мовлення, словотворчі ресурси, граматичні норми української мови.

На наш погляд, одним із важливих способів підвищення грамотності студентів $\epsilon$ різноманітні диктанти за текстами документів. Вони сприяють удосконаленню мовленнєвих навичок, допомагають зміцнити орфографічну, пунктуаційну, стилістичну грамотність студентів. Ми пропонуємо практичні вправи з українського ділового мовлення у формі диктантів:

- диктанти-переклади ділових текстів, що спрямовані на вироблення навичок перекладу з російської мови на українську, допомагають усвідомити явища кожної мови, збагачують культуру усного й писемного ділового мовлення;

- диктанти 3 опорними словами (мовними кліше, діловими термінами, професіоналізмами), вживаними в текстах ділових паперів; особливість таких у тому, що диктується не весь текст, а кілька ключових слів, спираючись на які, студенти складають текст; такі диктанти доцільно застосовувати для перевірки засвоєння теоретичного матеріалу за відповідним параграфом;

- коментовані (пояснювальні) диктант, що проводяться на основі текстів документів 3 метою виявлення знань студентів із синтаксису ділових текстів, який має свої особливості;

- розподільні диктанти, за допомогою яких визначають рівень оволодіння діловими термінами, діловою лексикою, фразеологією; під час цих диктантів студенти розподіляють слова, словосполучення на певні групи;

- творчі диктанти, що дають змогу реалізувати вміння добирати синоніми, пароніми, до слів поданих у тексті. Виконуючи такі вправи, студенти практикуються в заміні граматичних, стилістичних форм на інші, знаходять потрібні за змістом слова для складання тексту документа.

Різноплановою $є$ робота над текстами, що містять теоретичний матеріал. Доцільно використовувати завдання на складання текстів для перевірки знань теорії. Ефективним є також складання запитань і відповідей у формі діалогу до кожного параграфа, що розвиває діалогічне ділове мовлення. 
Цікаві для студентів і завдання на дослідження як мови текстів 3 викладом теоретичного матеріалу, так і мови текстів документів.

В ході дослідження автор статті приходить до висновку, що до вивчення ділового текстотвору треба підходити творчо, беручи до уваги рівень знань студентів, i не забувати про те, що текст як реальна комунікативна одиниця документа виконує ще й важливу виховну функцію. Бездоганно відредагований i оформлений, він $\epsilon$ складником репутації, додатковою рекламою, частиною іміджу підприємства, установи, організації, де працюватимуть студенти, своєрідною візитною карткою, свідченням високої культури управління.

\section{Література:}

1. Бабич Н. Д., Герман К. Ф., Скаб М. В. Культура фахового мовлення : навч. посіб. Чернівці : Книги. XXI, 2011. 528 с.

2. Ботвина Н. В. Офіційно-діловий та науковий стилі української мови : навч. посіб. Київ, 2001. $264 \mathrm{c}$.

3. Мамрак А. В. Українське документування: мова та стиль : навч. посіб. 3-є вид. Київ : Центр навч. літ., 2004. 364 с.

4. Михайлик В. О. Українська мова професійного спрямування : навч. посіб. Київ : Професіонал, 2005. 496 с.

5. Середницька А. Я., Куньч 3. Й. Українська мова за професійним спрямуванням : навч. посіб. Київ, 2012. 215 с.

\section{References:}

1. Babych, N. D., Herman, K. F. and Skab, M. V. (2011), Kul'tura fakhovoho movlennya [The culture of professional broadcasting], Knyhy, Chernivtsi, $528 \mathrm{p}$.

2. Botvyna, N. V. (2001), Ofitsiyno-dilovyy ta naukovyy styli ukrayins'koyi movy [Official-business and scientific styles of the Ukrainian language], Kyiv, $264 \mathrm{p}$.

3. Mamrak, A. V. (2004), Ukrayins'ke dokumentuvannya: mova ta styl' [Ukrainian documentation: language and style], Tsentr navch. lit., Kyiv, 364 p.

4. Mykhaylyk, V. O. (2005), Ukrayins'ka mova profesiynoho spryamuvannya [Ukrainian language of professional orientation], Profesional, Kyiv, 496 p.

5. Serednyts'ka, A. Ya. and Kun'ch, Z. Y. (2012), Ukrayins'ka mova za profesiynym spryamuvannyam [Ukrainian language by professional direction], Kyiv, 215 p.

\section{Natalija Ostrianska}

\section{TEXT OF THE DOCUMENT IS AN IMPORTANT COMMUNICATIVE COMPONENT OF WRITTEN BUSINESS LANGUAGE}

The purpose of the article is to comprehend and analyze the peculiarities of the text of the document as a communicative unit of written business language.

Important communicative qualities of written business language are concentrated in the main element of the document, in the unit of written language - the text. The defining function of the text is to be a means of social communication in all spheres of public life.

The text and its actual implementation is the problem of developing a culture of 
writing, the solution of which involves knowing the laws of logical and lexical word compatibility, the ability to use verbal formulas, distinguish the stylistic features of texts, and select appropriate language material for them.

The text as the main element of writing has such communicative qualities: brevity, consistency of presentation of the material, conciseness, semantic accuracy, consistency, objectivity, simplicity, expressiveness of language and style and accuracy of thought. They are expressed in language constructs and verbal formulas of texts of different levels (reports, business letters, contracts, orders), in logical elements (introduction, evidence, conclusions).

In the practice of modern office work, general requirements have been developed for the creation of texts of documents, some certain basic rules that ensure the realization of communicative qualities of business language and compliance with lexical, grammatical and stylistic norms.

The text of the document is the basis for the use of didactic materials for various educational work.

In our opinion, an important form of educational work on the formation of communication skills is the editing of texts of documents.

Tasks and exercises on the correct choice of synonyms, grammatical forms for compiling the text of the document form the ability of students to distinguish the meanings of words, develop a sense of language and intuition.

In the course of the study, the author of the article comes to the conclusion that it is necessary to be creative in studying business language, taking into account the level of students' knowledge, and not to forget that the text, as a real communicative unit of the document, also performs an important educational function. When flawlessly edited and formatted, the text is a part of the reputation, additional advertising, a part of the image of the enterprise, institution, organization where students will work, a kind of business card, and a sign of a high management culture.

Keywords: document, text, communicative qualities, culture of paperwork, oral activity.

\section{Наталія Острянська}

\section{ТЕКСТ ДОКУМЕНТА - ВАЖЛИВА КОМУНІКАТИВНА СКЛАДОВА ПИСЕМНОГО ДІЛОВОГО МОВЛЕННЯ}

Мета статті - осмислити й проаналізувати особливості тексту документа як комунікативної одиниці писемного ділового мовлення.

Важливі комунікативні якості писемного ділового мовлення зосереджені в головному елементі документа, тобто одиниці писемного мовлення - тексті. Визначальна функція тексту - бути засобом соціальної комунікації в усіх сферах суспільного життя.

Текст і фактична реалізація його - це та проблема вироблення культури письма, вирішення якої передбачає знання законів логічної й лексичної сполучуваності слів, уміння користуватися словесними формулами, розрізняти стильові особливості 
текстів, добирати до них відповідний мовний матеріал.

Текст як основний елемент писемного мовлення має такі комунікативні якості, як стислість, послідовність викладу матеріалу, лаконічність, смислова точність, логічність, об'єктивність, простота, виразність мови й стилю, влучність думки. Вони знаходять своє вираження в мовних конструкціях і словесних формулах текстів різного рівня (звітах, ділових листах, договорах, наказах), у логічних елементах (вступі, доказах, висновках).

У практиці сучасного діловодства вироблені загальні вимоги до створення текстів документів, основні правила, які забезпечують реалізацію комунікативних якостей ділового мовлення, додержання лексичних, граматичних, стилістичних норм.

Текст документа $є$ основою використання дидактичного матеріалу для різних навчальних робіт.

На нашу думку, важливою формою навчальної роботи 3 формування комунікативних умінь і навичок є редагування текстів документів.

Завдання і вправи на правильний вибір синонімів, граматичних форм для складання тексту документа формують уміння студентів розрізняти значення слів, розвивають чуття мови, інтуїцію.

У результаті дослідження автор статті доходить висновку, що до вивчення ділового текстотвору треба підходити творчо, беручи до уваги рівень знань студентів, i не забувати, що текст як реальна комунікативна одиниця документа виконує ще й важливу виховну функцію. Бездоганно відредагований i оформлений, він $\epsilon$ складником репутації, додатковою рекламою, частиною іміджу підприємства, установи, організації, де працюватимуть студенти, своєрідною візитною карткою, свідченням високої культури управління.

Ключові слова: документ, текст, комунікативні якості, культура діловодства, мовленнєва діяльність.

Ostrianska Natalija - Senior Lecturer of the Department of Documentation and Ukrainian Language Faculty of Humanities of the National Aerospace University «Kharkiv Aviation Institute».

Острянська Наталія - старший викладач кафедри документознавства та української мови гуманітарного факультету Національного аерокосмічного університету ім. М. Є. Жуковського «Харківський авіаційний інститут».

e-mail: ostrianskaya_nata@ukr.net

Надійшла до редакції 04.03.2019. Розглянута на редколегії 27.08.2019.

\section{Рецензенти:}

Кандидат філологічних наук, доцент, доцент кафедри документознавства та української мови гуманітарного факультету Національного аерокосмічного університету ім. М. Є. Жуковського «ХАI» Медведь О. В.

Кандидат психологічних наук, доцент, завідувач кафедри психології Національного аерокосмічного університету ім. М. Є. Жуковського «ХАІ» Жидко М. Є. 